\title{
THE EFFECTS OF ANGLE OF ATTACK, REYNOLD NUMBERS AND WINGLET STRUCTURE ON THE PERFORMANCE OF CESSNA 172 SKYHAWK
}

\author{
Henny Pratiwi
}

Aeronautics Department

Adisutjipto College of Technology

Jl. Janti Blok R Lanud Adisutjipto

henny_pratiwi@stta.ac.id

\begin{abstract}
This research aims to investigate the effects of angle of attack, Reynold numbers and winglet design on the performance of Cessna 172 Skyhawk aircraft. Winglets improve efficiency by diffusing the shed wingtip vortex, which reducing the drag due to lift and improving the wing's lift-to-drag ratio. In this research, the specimens are the duplicated of Cesnna 172 Skyhawk wing with 1:40 ratio made of balsa wood. There are three different winglet designs that are compared with the one without winglet. The experiments are conducted in an open wind tunnel to measure the lift and drag force with Reynold numbers of 25,000 and 38,000 . It can be concluded that the wings with winglets have higher lift coefficient than wing without winglet for both Reynold numbers. It was also found that all wings with winglets generally have higher lift-to-drag ratio than wings without winglet where the winglet at cant angle 45 degree has the highest value.
\end{abstract}

Keyword : winglet, angle of attack, Reynold numbers, lift-to-drag ratio, Cessna 172 Skyhawk.

Abstrak

Penelitian ini bertujuan untuk mengetahui pengaruh sudut serang, bilangan Reynolds dan desain winglet terhadap performa pesawat Cessna 172 Skyhawk. Winglet meningkatkan efisiensi dengan memecahkan vorteks pada wingtip sehingga dapat mengurangi gaya hambat dan meningkatkan rasio perbandingan gaya angkat dan gaya hambat. Spesimen merupakan duplikasi dari sayap pesawat Cesnna 172 Skyhawk dengan rasio 1:40 yang terbuat dari kayu balsa. Terdapat tiga desain winglet yang berbeda yang kemudian dibuat perbandingan dengan sayap tanpa winglet. Ekperimen dilakukan pada sebuah terowongan angin model terbuka untuk mengukur besarnya gaya angkat dan gaya hambat untuk bilangan Reynolds 25.000 dan 38.000. Setelah melakukan penelitian dapat diketahui bahwa semua sayap yang dipasang winglet memiliki koefisien gaya angkat yang lebih besar jika dibandingkan dengan sayap tanpa winglet untuk kedua bilangan Reynold. Dapat disimpulkan juga bahwa secara umum semua sayap yang dipasang winglet memiliki perbandingan koefisien gaya angkat dan gaya hambat yang lebih besar jika dibandingkan dengan sayap tanpa winglet dimana winglet cant bersudut 45 derajat merupakan winglet yang memiliki perbandingan koefisien gaya angkat dan gaya hambat tertinggi.

Kata kunci : winglet, sudut serang, bilangan Reynold, rasio koefisien gaya angkat dan gaya hambat, Cessna 172 Skyhawk. 


\section{Introduction}

One of the primary obstacles limiting the performance of aircraft is the drag that the aircraft produces. This drag is created due to the vortices shed by an aircraft's wings, which causes the local relative wind downward and generated a component of the local lift force in the direction of the free stream called induced drag. The strength of this induced drag is proportional to the spacing and radii of these vortices. By designing wings which force the vortices farther apart and at the same time create vortices with large core radii, one may significantly reduce the amount of the drag the aircraft induces (Hossain et al., 2011).

The use of winglets which is made of Whitcomb for improving aircraft aerodynamic efficiency became topic of many researches. Smith et al. (2001) have investigated the performance analysis of a wing with multiple winglets. Five winglets made of aluminum plates with rounded leading edges were used in the experiment. The results show that certain multi-winglet configurations reduced the wing induced drag and improved lift-to-drag ratio by $15 \%$ until $30 \%$ compared with the wing without winglet. The effect of winglets induced tip vortex structure on the performance of subsonic wings has examined by Narayan et al. (2016). They designed three types of winglets, i. e. Blended, BMAX and Multi-tipped winglets. The blended winglet has cant angle of $75^{\circ}$. BMAX winglet is a double blended winglet which has an angle of $\left(65^{\circ},-65^{\circ}\right)$. Multi tipped winglets are 3 different winglets, multi-tip 2, multi-tip-3, multi-tip-4 with the angle of $\left(10^{\circ}, 50^{\circ}\right),\left(10^{\circ}, 35^{\circ}, 60^{\circ}\right)$ and $\left(10^{\circ}, 26^{\circ}\right.$, $42^{\circ}, 58^{\circ}$ ), respectively. The result showed that the multi-tip-4 winglet has the highest lift coefficient, but the best lift to drag ratio was obtained by multi-tip-3 winglet.

Aerodynamic principle which is more detailed of winglets is discussed in another investigation. In general, a winglet produces a side force, which has a forward component because of the sidewash produced by the wing tip circulation. This forward component of the lift acts as a thrust force reducing the aircraft induced drag, which is about $40 \%$ of the total drag in cruise and $80-90 \%$ of the total drag in the second climb segment (Kroo, 2005).

Wingtip devices are used to improve the efficiency of fixed-wing aircraft. Winglets can also improve aircraft handling characteristics. The wingtip devices increase the lift generated at the wingtip, and reduce the lift-induced drag caused by wingtip vortices, improving lift-todrag ratio. Winglets improve efficiency by diffusing the shed wingtip vortex, which in turn reduces the drag due to lift and improves the wing's lift over drag ratio (Azlin et al., 2011). Winglets increase the effective aspect ratio of a wing without adding greatly to the structural stress and hence necessary weight of its structure.

There is investigation that did the analytical calculations and computational simulations during the preliminary design phase. The results showed that the wing's contribution to the aircraft's total drag was $40 \%$ at loiter conditions, ranging approximately between $30 \%$ and $70 \%$ for different angles of attack. Therefore, minimizing the drag in wing can help in a large amount of enhancing the overall aerodynamic efficiency (Hossain et al., 2011).

Bojja and Garre (2013) have investigated the Boeing 767 wing and attached the winglet to analyze the performance where the winglets are mounted on the wing tips as the vertical extensions. The winglets with different angle of attacks have been observed to see the performance. Wing and winglet are designed in Catia V5 then analyzed in Ansys CFX workbench and Fluent to reduce the vortices at the wingtips. The results showed that the blended winglet gives the better performance compared to the wing without winglet and wing with circular winglet. The drag coefficient obtained for the blended winglet is less in all angles of attack. The best drag coefficient is obtained when the wing is kept at 12 degree angle of attack.

Büscher et al. (2006) have tried to design and optimize the winglet shape in order to obtain the minimum drag of the wing. However, the addition of winglet will cause the change 
in wing structural weight. Therefore the optimization in aerodynamic could result in a winglet with the addition of weight. This additional weight may tolerate the effect of drag reduction in an aircraft take-off weight or even fuel weight minimization. Besides, the increase in wing weight should be limited for additional winglets to minimize the amount of modifications in the wing structure.

The Cessna 172 Skyhawk has been widely used for general rental, flight instruction and family transport. The newer models of the 172 are in popular demand since they are affordable, simple to handle and are the perfect aircraft for a small family today. The good performance of Cessna 172 Skyhawk, i.e. reliability and endurance, have made it become one of the best aviation aircraft in the world, and is loved by thousands of pilots around the world. In this paper we investigate the effect of angle of attack variation with different winglet and speed in order to find the optimum performance of winglet Cessna 172 Skyhawk.

\section{Methods}

The force measurements was carried out in an open-type and subsonic low-speed wind tunnel located at Sekolah Tinggi Teknologi Adisutjipto. Dimension of the test section is 30 $\mathrm{mm} \times 30 \mathrm{~mm} \times 48 \mathrm{~mm}$. The freestream velocity, $\mathrm{U} \infty$, near the center of the test section can be operated from 5 to $30 \mathrm{~m} / \mathrm{s}$. The testing of half-wing with and without winglet is the rectangular NACA2412 airfoil with the chord length (c) of $40.75 \mathrm{~mm}$ and $7.52 \mathrm{AR}$, which has the scale of 1:40 compared with the real Cessna 172 Skyhawk wing. There are three different winglet designs that are compared with the one without winglet which are made of balsa wood. The winglet designs are the winglet wing at cant angle $45^{\circ}(\mathrm{CW})$, the multi winglet with $20^{\circ}, 0^{\circ},-20^{\circ}$ (MW1), the multi winglet with $0^{\circ}, 22.5^{\circ}, 45^{\circ}$ (MW2) and the one without winglet (WW). The MW1 and MW2 specimens are measured from zero relative.

\section{Results and Discussions}

Various winglet designs have been done to examine the efficiency of the addition of winglets to improve the performance of a wing subsonic flow. The force measurement was used to determine the lift coefficient, drag coefficient and L/D ratio. There are four types of specimens, WW (without winglet), CW (winglet wing at cant angle $45^{\circ}$ ), MW1 (multi winglet with $20^{\circ}, 0^{\circ},-20^{\circ}$ ) and MW2 (multi winglet with $0^{\circ}, 22.5^{\circ}, 45^{\circ}$ ). The specimen used was NACA 2412 wing at different air velocity.

The lift coefficient at Reynold numbers of 25,000 increases in a linear trend with angle of attack up to 12 degrees as shown in Fig. 1, after which the wing stalls. The cambered nature of the 2412 airfoil ensures a positive coefficient even at zero degrees angle of attack. The winglet wing at cant angle $45^{\circ}$ has provided a slightly higher stall angle due to its ability to delay flow separation emanating from the tip. However, accurate prediction of post stall performance requires transient simulation, which is computationally intensive and also beyond the scope of this paper. It can be seen that the addition of winglet wing at cant angle $45^{\circ}$ winglet offers an $22 \%$ increase in lift coefficient as compared to the wing without winglet. 


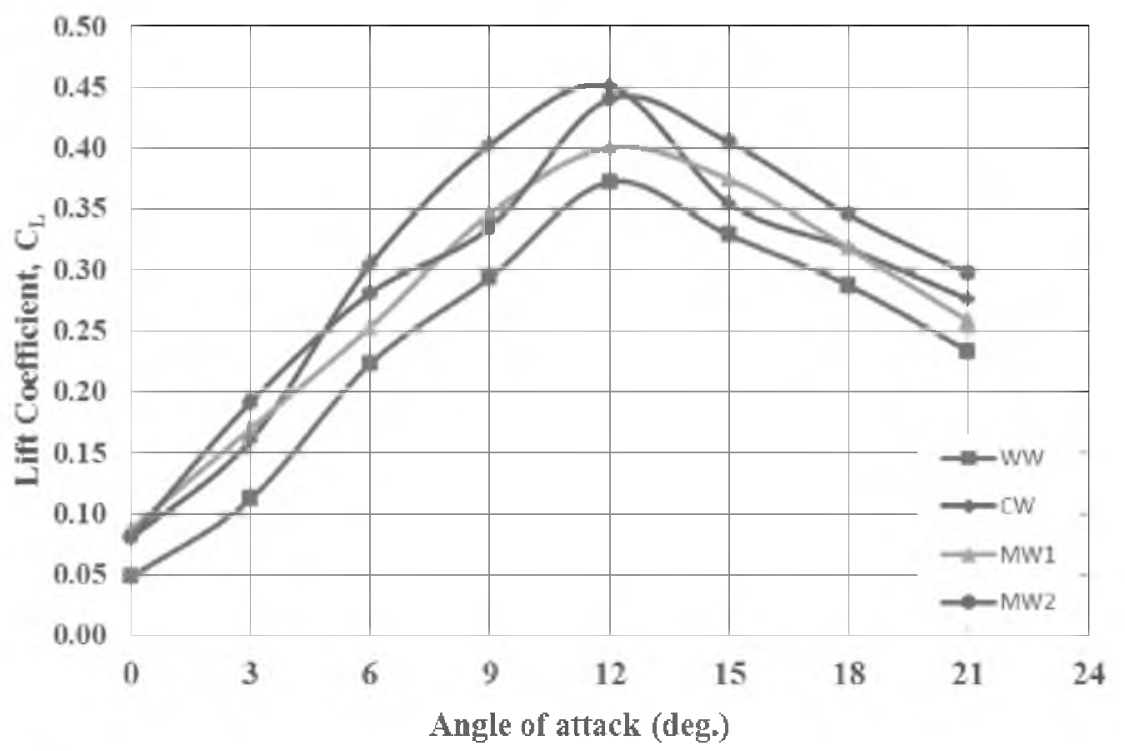

Figure I Variation of lift coefficient with angle of attack for different winglet shapes at Reynold numbers of 25,000.

The influence of wing tip devices at Reynold numbers of 25,000 with varying vortex distributions can be quantitatively observed from the coefficient of drag plotted against angle of attack in Fig 2. The coefficient of drag increases until the stall angle of attack after which there is a steep increase. There exists a cross over point for drag curves of all type of winglets at 6 degree where onwards the induced drag significantly increases as compared to the skin friction. The winglet wing at cant angle $45^{\circ}$ winglet is able to maintain a lower $C_{D}$ as compared to the other winglets due to the low tip vortex. Both multi winglet designs have higher $C_{D}$ because higher number of tips in the winglet leads to a significant increase in the frictional drag thus making it counterproductive.

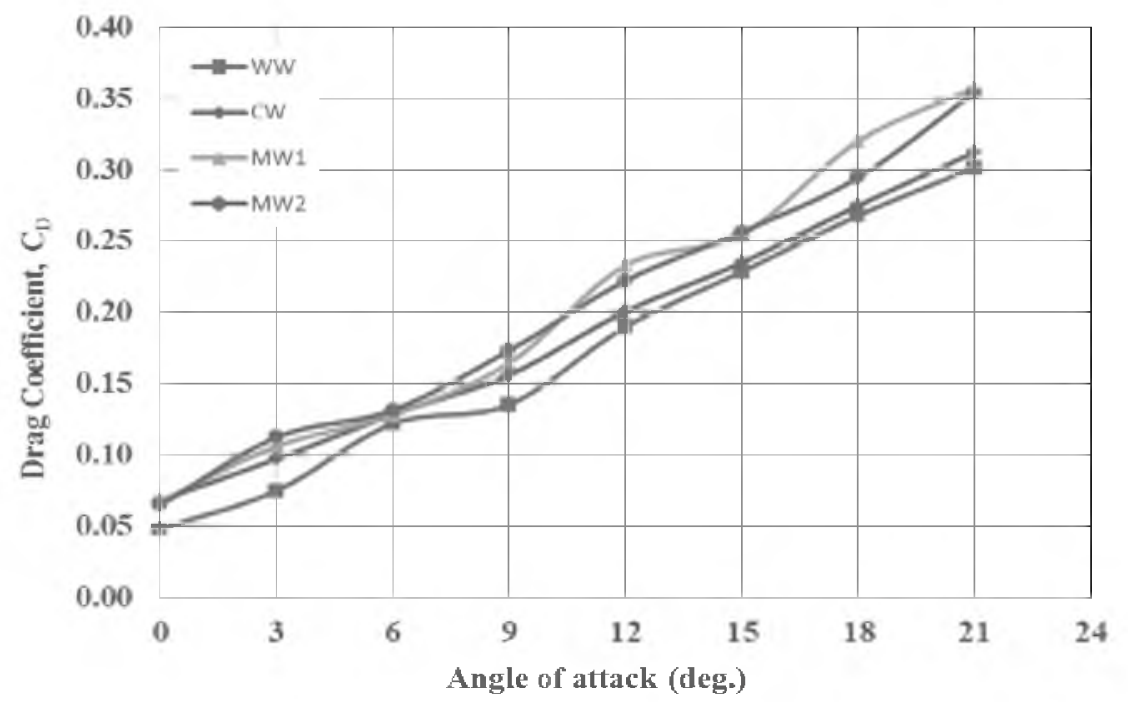

Figure 2 Variation of drag coefficient with angle of attack for different winglet shapes at Reynold numbers of 25,000 . 
Although individual variations of lift and drag coefficients for different winglet designs are analyzed, it is the ratio of lift and drag coefficient that signifies aerodynamic efficiency in the wing design, as the L/D ratio improves the climb speed, take-off and landing performance along with range. Therefore discussion of $C_{L} / C_{D}$ variation is vital for the completeness of present research. To find the optimum design that gives maximum lift to drag ratio at Reynold numbers of $25,000, C_{L} / C_{D}$ versus angle of attack is presented in Fig.3. The $C_{L} / C_{D}$ ratio initially increases in a linear fashion with increase in angle of attack and attains its maximum value at about 9 degrees. All three wing designs deliver their best performance at roughly this angle of attack. However their relative magnitude of $C_{L} / C_{D}$ differs. At 9 degrees angle of attack the $\mathrm{C}_{\mathrm{L}} / \mathrm{C}_{\mathrm{D}}$ ratio obtained with winglet wing at cant angle $45^{\circ}$ design which is almost 19\% higher than that obtained for base line design.

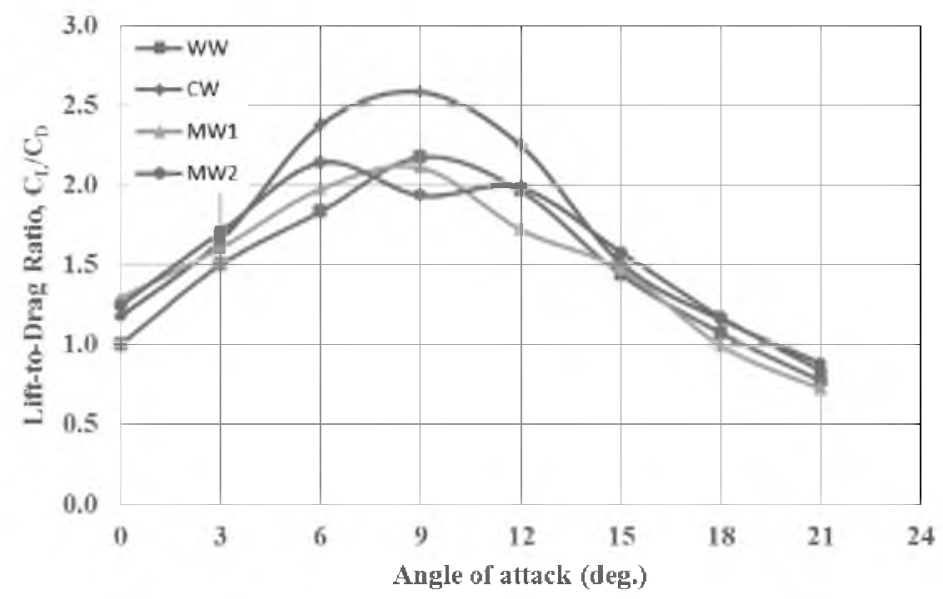

Figure $3 C_{L}$ by $C_{D}$ vs angle of attack for different winglet shapes at Reynold numbers of 25,000 .

For different Reynold numbers, which is 38,000 , all winglet designs have lift coefficient which is almost the same trend with the 25,000 (Figure 4). From the figure it could be observed that the lift increases with increase in angle of attack. It could also be seen that the wings with winglets have higher lift coefficient $\mathrm{C}_{\mathrm{L}}$ than wing without winglet about $13 \%$ to $27 \%$. There exists a cross over point for drag curves of multi winglets 2 and winglet wing at cant angle 45 degree at 12 degree angle of attack, but higher $17 \%$ than the 25,000 one. It means that the increasing in air speed could improve the lift profile of aircraft.

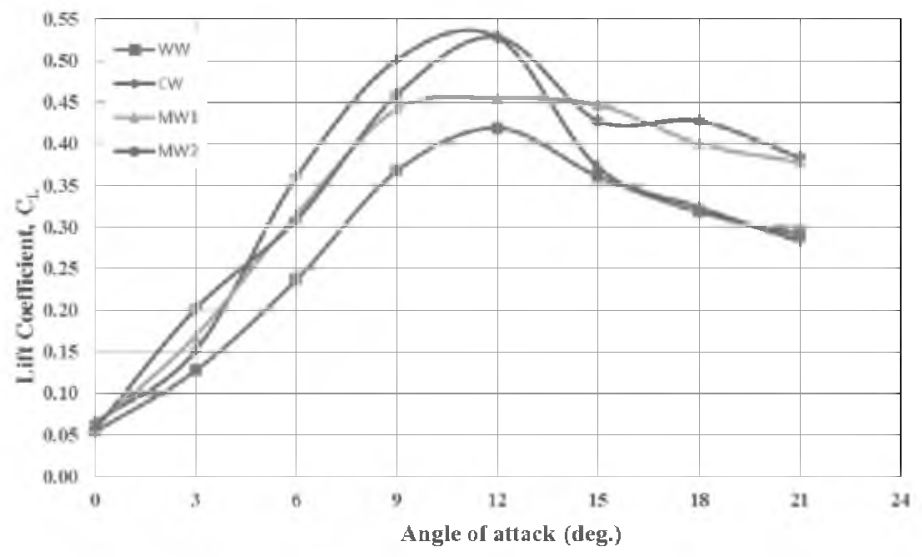

Figure 4 Variation of lift coefficient with angle of attack for different winglet shapes at Reynold numbers of 38,000 . 
Not only the lift coefficient but also the drag coefficient increase for Reynold numbers of 38,000 (Fig. 5). It is observed that the drag increases with the increase of the angle of attack. The effect of wings with different winglet is not important at 0 degree angle of attack due to low induced drag and the wings with winglet have more surface area, which caused the friction drag to increase. At high angle of attack, the induced drag increase and then the effect of winglet increase to reducing induced drag. It was found that the highest drag coefficient, $C_{D}$ increases about $19 \%$ wing with winglet compared to wing without winglet and $7 \%$ compared to wing with Reynold numbers of 25,000 for the same winglet design.

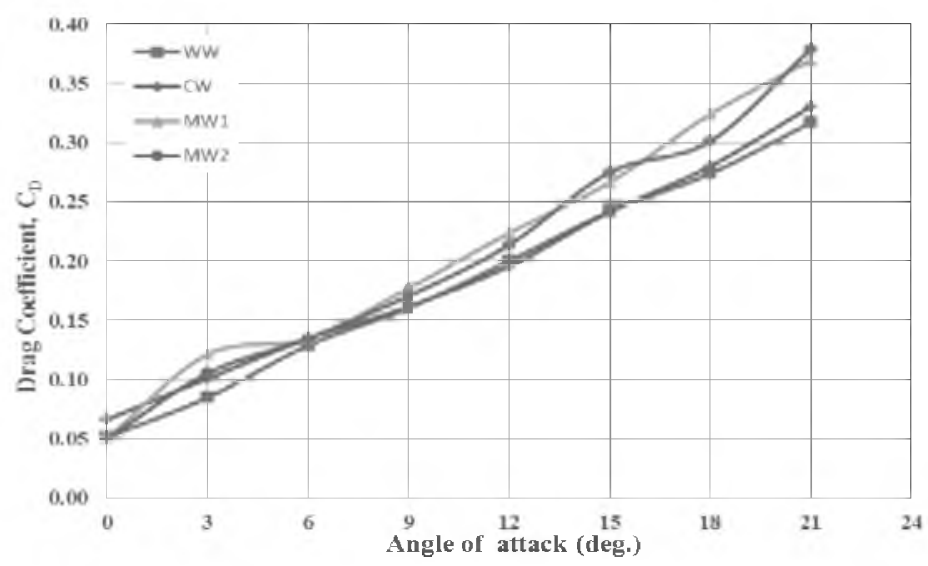

Figure 5 Variation of drag coefficient with angle of attack for different winglet shapes at Reynold numbers of 38,000 .

Figure 6 showed that the wings with winglets have higher lift-to-drag ratio than wings without winglet. The winglet wing at cant angle 45 degree $(\mathrm{CW})$ has the highest lift-to-drag ratio, $\mathrm{C}_{\mathrm{L}} / \mathrm{C}_{\mathrm{D}}$ by about $35 \%$ at 9 degree angle of attack comparing to wing without winglet. This is followed by MW2 which is second highest lift-to-drag ratio, $\mathrm{C}_{\mathrm{L}} / \mathrm{C}_{\mathrm{D}}$ by about $18 \%$ at the same angle of attack comparing to the wing without winglet. The lift to drag ratio at Reynold numbers of 38,000 is higher by about $20 \%$ for the same winglet design and angle of attack (winglet wing at cant angle 45 degree winglet, 9 degree angle of attack) compared to the one at 25,000 .

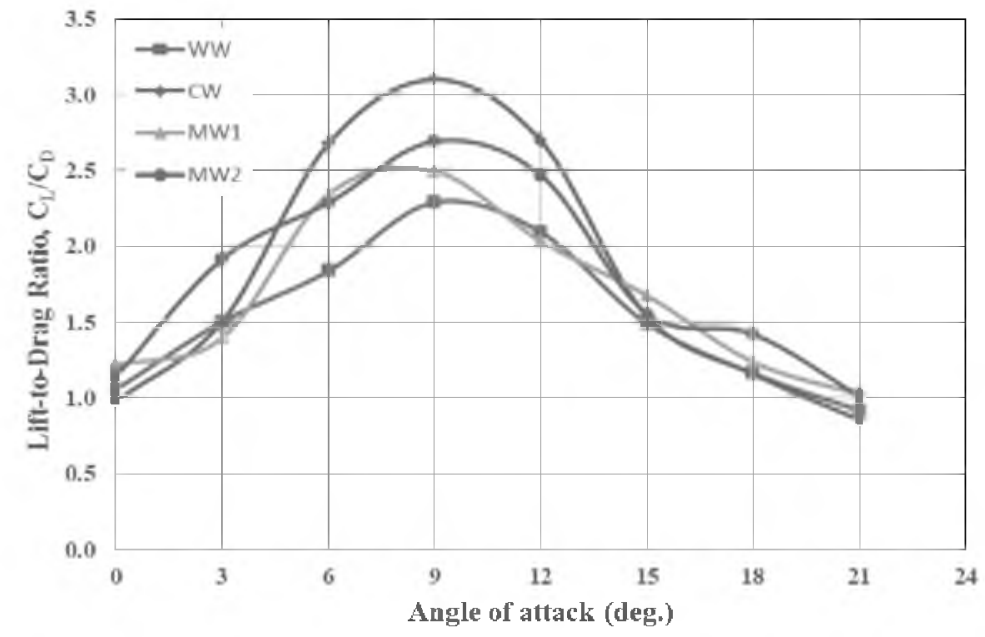

Figure $6 C_{L}$ by $C_{D}$ vs angle of attack for different winglet shapes at Reynold numbers of 38,000 . 


\section{Conclusions}

1. The wings with winglets have higher lift coefficient $\left(\mathrm{C}_{\mathrm{L}}\right)$ than wing without winglet by about $22 \%$ and $27 \%$ at angle of attack of 12 degree and winglet wing at cant angle $45^{\circ}$ for Reynolds number of 25,000 and 38,000 , respectively.

2. It was found that the highest drag coefficient $\left(C_{D}\right)$ is achieved by the multi winglet by about $7 \%$ for Reynolds number of 25,000 and $19 \%$ for Reynolds number of 38,000 compared to the wing without winglet at angle of attack 21 degree.

3. All wings with winglets are higher L/D than wings without winglet where the winglet wing at cant angle $45^{\circ}$ had the highest lift-to-drag ratio $\left(C_{L} / C_{D}\right)$ by about $19 \%$ and $35 \%$ respectively for Reynolds number of 25,000 and 38,000 at angle of attack of 9 degree.

\section{References}

Azlin, MA, Mat Taib, CF, Kasolang, S and Muhammad, FH, 2011, CFD Analysis of Winglets at Low Subsonic Flow, WCE, London, pp. 1-3.

Bojja, A, Garre, P, 2013, 'Analysis on reducing the induced drag using the winglet at the wingtip', International Journal of Engineering Research \& Technology (IJERT), vol. 2, pp. 51-53.

Bourdin, P, Gatto, A, Friswell, MI, 2006, 'The application of variable cant angle winglets for morphing aircraft control, in: 24th Applied Aerodynamics Conference, pp.5-8.

Büscher, A, Radespiel, R, Streit, T, 2006, 'Modelling and design of wing tip devices at various flight conditions using a databased aerodynamic prediction tool', Aerospace Science and Technology, vol. 10, pp. 668-678.

Hossain, A, Rahman, A, Iqbal, AKMP, Ariffin, M and Mazian, M, 2011, 'Drag Analysis of an Aircraft Wing Model with and without Bird Feather like Winglet', International Journal of Aerospace and Mechanical Engineering, vol. 5, no. 9, pp. 1894 - 1899.

Kroo, I, 2005, 'Nonplannar wing concept for increased aircraft efficiency, in Innovative Configurations and Advanced Concepts for Future Civil Aircraft', VKI Lecture Series, von Karman Institute for Fluid Dynamics, Rhode-St-Genese, Belgium.

Narayan, G, John, B, 2016, Effect of winglets induced tip vortex structure on the performance of subsonic wings, Aerospace Science and Technology, vol. 58, pp. 328 -340 . 
